\title{
The interrelationships between customer satisfaction, brand loyalty and relationship intentions of Generation Y consumers towards smart phone brands
}

\author{
P.G. Mostert *, D.J. Petzer and A. Weideman \\ WorkWell: Research Unit for Economic and Management Sciences, North-West University: Potchefstroom Campus \\ *To whom all correspondence should be addressed \\ pierre.mostert@up.ac.za
}

\begin{abstract}
Smart phone marketers are finding it difficult to maintain market share in a market characterised by fierce competition and continued new product development. Generation Y consumers generally have a good command of technology and engage in technology-related behaviour such as texting, tweeting and web-surfing. When it comes to the adoption of smart phone applications, it is believed that Generation $\mathrm{Y}$ is leading the way. To retain Generation Y consumers, it is critical for organisations to ensure that customer satisfaction is achieved, brand loyalty has to be generated and meaningful long-term relationships with these consumers should be established. In this regard, this study aims to determine the interrelationships between customer satisfaction, brand loyalty and the relationship intentions of Generation Y smart phone users. Selfadministered questionnaires were fielded among 395 Generation Y smart phone users living in Gauteng, South Africa. Results indicate significant and positive interrelationships between customer satisfaction, brand loyalty and relationship intention.
\end{abstract}

\section{Introduction}

Smart phone marketers are experiencing fierce competition in an increasingly competitive global market, where it is estimated that the number of smart phones shipped increased from 990 million units in 2013 to more than 1.3 billion units in 2014 (Danova, 2015). The growth in the smart phone market is expected to continue in the future, with forecasts indicating that the annual worldwide shipment volume will reach 1.9 billion units in 2019 (IDC, 2015), mainly due to the adoption of smart phones in emerging markets (Danova, 2015; IDC, 2015; Tshabalala, 2015). Despite the rapid growth in the smart phone market, marketers have to contend with continually changing technology (Mahadoo, 2010) and constant new product development driven by the need for enhanced handset capabilities and designs (Hong, 2012; Mahadoo, 2010). Smart phone marketers are consequently finding it increasingly difficult to maintain market share (Markets and Markets, 2011). It is therefore essential that smart phone marketers build relationships with their customers in an effort to retain them.

The purpose of building long-term relationships with customers is essentially that of retaining these customers and creating brand loyalty, which could result in positive longterm financial performance (Iglesias, Sauquet \& Montaña, 2011:632; Palmer, 2011:279). Although brand loyalty can be viewed as the long-term relationship between a customer and a specific brand or organisation (Liu, 2008:47), customer satisfaction serves as a precondition for brand loyalty (Egner, 2008:20; Kaplan \& Norton, 2006:20; Shimp, 2010:64). Customer dissatisfaction, on the other hand, can lead to brand switching and discontinued use of the product (Longenecker,
Petty, Palich \& Moore, 2009:380), lending credence to the idea that customers' intentions to exit a relationship are reduced if there is a high level of customer satisfaction (Purohit, 2004:2; Sunarto, 2007:211).

Despite the importance of ensuring customer satisfaction and brand loyalty in building customer relationships, organisations should realise that it is unwise to attempt to build relationships with all their customers, as they cannot all be served profitably, nor would they all want to form relationships with organisations or brands (Doyle, 2008:12; Kumar, Bohling \& Ladda, 2003:690; Tuominen, 2007:182). Instead, organisations should confine their efforts and resources to customers who show relationship intentions (Kumar et al., 2003:690).

Considering the challenges smart phone marketers are facing, an understanding of the way in which strong and profitable relationships are formed with young people (the so-called Generation Y) as well as how their brand loyalty is established could assist in implementing successful marketing plans and fostering long-term loyalty (Gorun, 2011; Gurău, 2012:110; Lazarevic, 2012:45), as it is believed that Generation $\mathrm{Y}$ is leading the way with their adoption of smart phones (Lesonsky, 2013).

Considering the importance of Generation $\mathrm{Y}$ as the leading purchasers of technological products, as well as their current and future purchasing power (Lazarevic, 2012:48; Meek, 2011), it was surprising that no research studies could be found that focused on the relationships between Generation Y's satisfaction, brand loyalty, relationship intention and related constructs within a technological product (for 
example, the smart phone) environment. Recognising this gap in the literature, the primary objective of this study was to investigate the interrelationships between Generation $Y$ consumers' satisfaction, brand loyalty and relationship intentions regarding smart phone brands.

\section{Literature review}

\section{Relationship marketing}

Palmer (2011:279) explains that, when organisations follow a relationship marketing approach, they focus on building long-term relationships by understanding their customers' needs and offering products and services to meet those needs as they go through their life cycle. Organisations that successfully build relationships with customers stand to benefit in a number of ways. These include being less vulnerable to competitors' attempts to lure their customers away, enhanced customer life-time value (Gamble, Stone, Woodcock \& Foss, 2006:180), reduced customer defection rates (Gamble et al., 2006:180), positive word-of-mouth recommendations, increased profit from repeat sales and customers' willingness to spend more with the organisation (Hoffman \& Bateson, 2011:385). The essence of relationship marketing is therefore to establish and maintain long-term customer relationships (Iglesias et al., 2011:632), as these relationships may increase customer retention and the concomitant profitability, as it is more profitable to retain existing customers than to recruit new ones (Jena, Guin \& Dash, 2011:22; Sweeney, Soutar \& McColl-Kennedy, 2011:292).

Despite these benefits to organisations, customers are not all equally profitable, nor do they all desire a long-term relationship with an organisation. This would mean that valuable resources could be ineffectively applied if the 'wrong' customers are targeted (Doyle, 2008:12; Hougaard \& Bjerre, 2003:130; Kumar et al., 2003:668,669; Tuominen, 2007:182). It is therefore essential to identify customers who want to respond to an organisation's relationship-building initiatives (i.e. customers with higher relationship intentions) and build relationship with them (Kumar et al., 2003:669).

\section{Relationship intention}

Kumar et al. (2003:669) define relationship intention as a customer's intention to build a relationship with a brand, a product or a service associated with an organisation. According to Kumar et al. (2003:670), it makes sense to invest in relationships with customers who have high relationship intentions, as they have formed an emotional attachment to the organisation. They are not opportunistic in their dealings with the organisation, are less price-sensitive, have a long-term relationship perspective, and could ultimately be more profitably served. Furthermore, Kumar et al. (2003:670) suggest that customers' relationship intentions comprise five sub-constructs: involvement, expectations, forgiveness, feedback and fear of loss of the relationship.
Involvement refers to the extent of a customer's interest in a product or service and its importance to the customer (Pride, Ferrell, Lukas, Schembri \& Niininen, 2012:115). Seiders, Voss, Grewal and Godfrey (2005:39) maintain that customer involvement serves as an instrument for developing customer relationships and organisations should identify highlyinvolved customers in order to construct long-term relationships with them. Accordingly, Kumar et al. (2003:670) propose that highly-involved customers experience a feeling of guilt and discomfort when they consider defecting to a competitor.

Customers have expectations when buying from an organisation (Kumar et al., 2003:670), based on their previous experience (Wilson, Zeithaml, Bitner \& Gremler, 2012:51). Therefore, these expectations serve as benchmarks against which actual performance is measured (Wilson et al., 2012:51), thereby directly influencing customer satisfaction (Choy, Lam \& Lee, 2012:14). Kumar et al. (2003:670) argue that customers with higher expectations are more likely to develop relationships with organisations or brands.

Kumar et al. (2003:670) posit that, despite pre-existing expectations, customers with high relationship intentions are more likely to forgive an organisation, even if their expectations are not always met. If customers are dissatisfied when their expectations are not met, they have a number of strategic choices: they can decide not to do anything (Lovelock \& Wirtz, 2011:372-373), tell their friends or family about their negative experience (Humphrey, 2011:125), defect to competitors (Palmer, 2011:75) or give the organisation some feedback (Dunne, Lusch \& Carver, 2011:107). Given these possible strategies, Kumar et al. (2003:670) argue that customers with high relationship intentions are likely to provide feedback (positive and negative) to the organisation without expecting any reward, whereas customers with low relationship intentions probably give negative feedback and expect a reward or some form of compensation.

Finally, the fear of relationship loss stems from customers' fear of losing special privileges and benefits. Customers also fear the relational costs (including emotional and psychological consequences) of switching from one organisation or brand to another (Babin \& Harris, 2011:272). Kumar et al. (2003:670) therefore believe that customers who fear the loss of their relationship with an organisation typically demonstrate higher levels of relationship intention.

\section{Customer satisfaction}

Customer satisfaction can be defined as a customer's evaluation of the extent to which the actual performance of a product or service has met the customer's expectations, resulting in either pleasure or disappointment (Helgesen, 2007:96; Nijssen \& Van Herk, 2009:280). The key to studying customer satisfaction from the perspective of relationship marketing lies in the awareness that satisfaction serves as the foundation for long-term relationships (Goldstein, 2009:xi). This view is echoed by Keiningham, 
Cooil, Aksoy, Andreassen and Weiner (2007:67), who explain that customer satisfaction is an essential indicator of whether or not customers are willing to commit to a long-term relationship with an organisation.

Lee, Johnson and Gahring (2008:146) maintain that the expectancy disconfirmation theory has been the most influential one in explaining customer satisfaction. According to this theory, customer satisfaction is measured by the discrepancy between customers' perceptions and their expectations (Golder, Mitra \& Moorman, 2012:12; Lee et al., 2008:146). Disconfirmation is therefore the result of a discrepancy between customer expectations and perceived performance (Lee et al., 2008:146). Further, the wider the gap between customers' expectations and the perceived performance, the greater will be their satisfaction or dissatisfaction (Hutcheson \& Moutinho, 1998:706). According to the expectancy disconfirmation theory, customers are satisfied if the performance meets their expectations, and delighted when the performance exceeds them. However, they will be dissatisfied if the performance is below their expectations (Lee et al., 2008:146; Thomas, Lewison, Hauser \& Foley, 2007:144).

Despite the fact that achieving high levels of customer satisfaction is important, given the general belief that satisfaction leads to customer loyalty (Chandrasekar, 2010:152; Rao, 2011:114), customers are likely to switch to a competitor when they are dissatisfied (Rao, 2011:114). Regarding the influence of customer satisfaction on brands, Hofmeyr and Rice (2003:85) and Levine (2003:204,206) found that customer satisfaction with a specific brand is essential to brand loyalty and that without it brand loyalty cannot exist.

\section{Brand loyalty}

Brand loyalty refers to a customer's deeply-held commitment to continue purchasing a preferred brand consistently over time rather than switching to a competitor brand (Oliver, 1997:392; Wankel, 2009:181). The concept of brand loyalty has motivated interest among academics and practitioners, as it is thought to represent one of the most important factors explaining customer brand choices (Jensen \& Hansen, 2006:442). Hofmeyr and Rice (2003:86) and Liu (2008:47) argue that, as customers have to desire a product before marketers can consider them to be loyal, brand loyalty can be viewed as the long-term relationship between a customer and a specific brand or organisation.

In considering brand loyalty, marketers should be aware that three degrees of brand loyalty can be identified: brand recognition, brand preference and brand insistence (Ferrell \& Hartline, 2011:204; Pride \& Ferrell, 2011:400). Brand recognition, the mildest form of brand loyalty (Pride et al., 2012:202), occurs when customers know about a specific brand and would consider it when making a purchase (Ferrell \& Hartline, 2011:204). The brand would serve as a possible alternative when the purchaser's preferred brand is unavailable or when other available brands are considered unfamiliar (Pride \& Ferrell, 2011:400). For this reason, organisations try to foster brand recognition in an effort to create brand preference (Alamro \& Rowley, 2011:477). Brand preference follows when a specific brand is preferred to competitive brands (Ferrell \& Hartline, 2011:204). However, despite demonstrating brand preference, customers accept a substitute brand when their preferred brand is unavailable. They do this rather than expending additional effort in finding and purchasing the preferred brand (Pride $e t$ al., 2012:202). Brand insistence, the strongest form of brand loyalty, means that customers do not accept substitutes but instead do virtually anything to find and purchase their preferred brand, even delaying the purchase until the preferred brand can be found (Ferrell \& Hartline, 2011:204; Pride \& Ferrell, 2011:400).

The significance of pursuing brand loyalty lies in the fact that brand-loyal customers offer a number of benefits to organisations, including the ability to achieve a sustainable competitive advantage (Pride \& Ferrell, 2011:401; Sharma, Singh, Deepak \& Agrawal, 2010:239), provide easier brand extensions which can lead to brand equity (Sharma et al., 2010:239), and ultimately produce higher profit margins, seeing that brand loyal customers are usually less sensitive to price increases (O’Guinn, Allen \& Semenik, 2011:31).

\section{Hypotheses and theoretical model development}

\section{The relationship between customer satisfaction and brand loyalty}

Customer satisfaction is a major determinant of both repeat and future purchasing behaviour, as it serves as a precondition for brand loyalty (Shimp, 2010:64; Egner, 2008:20; Kaplan $\&$ Norton, 2006:20). Chandrasekar (2010:152), Hofmeyr and Rice (2003:85) and Levine $(2003: 204,206)$ concur with this notion that customer satisfaction leads to brand loyalty because without customer satisfaction there can be no brand loyalty. Tuu, Olsen and Linh's $(2011: 368,374)$ research findings support this view by establishing that customer satisfaction had a positive effect on loyalty. Concerning Generation Y, a number of studies (Bresler, 2013:140,162; Foscht, Schloffer, Maloles III \& Chia, 2009:234; Kumar, \& Lim, 2008:573; Veloutsou \& McAlonan, 2012:130) established that Generation Y consumers' satisfaction predict their loyalty. The following alternative hypothesis is accordingly formulated:
$\boldsymbol{H}_{1}$ : There is a direct positive relationship between customer satisfaction and brand loyalty to smart phone brands among Generation Y consumers.

The relationship between customer satisfaction and relationship intention

It is generally believed that customer satisfaction is crucial for the successful development of customer relationships (Goldstein, 2009:xi; Hofmeyr \& Rice, 2003:85; Levine, 2003:204, 206; Raciti, Ward \& Dagger, 2013:605). Sunarto $(2007: 211)$ suggests that, since the intention to leave a 
relationship is reduced by a high level of customer satisfaction, customer satisfaction increases customers' relationship intentions. Research by Mentz (2014:233) and Wei, Li, Burton and Haynes (2012:60) support this view by establishing a positive relationship between relationship intention and customer satisfaction. Concerning Generation $\mathrm{Y}$, research found a positive relationship between satisfaction and behavioural intentions (Foscht et al., 2009:241) and furthermore established that Generation Y's satisfaction predicts their relationship intentions (Bresler, 2013:140,162). The following alternative hypothesis is accordingly formulated:

$\boldsymbol{H}_{2}$ : There is a direct positive relationship between customer satisfaction and relationship intention among Generation $Y$ consumers regarding smart phone brands.

\section{The relationship between brand loyalty and relationship intention}

Despite an increasing number of organisations who have shifted their focus to relationship marketing in an effort to increase customer loyalty and ultimately retain customers (Adjei \& Clark, 2010:73; Mende, Bolton \& Bitner, 2013:125; Wang \& Ha, 2011:337), it is not necessarily organisations' efforts but rather customers' relationship intentions that determine whether or not they will be willing to form longterm relationships with organisations (Liu, 2007:35). Organisations therefore stand a better chance of building brand loyalty with customers who show higher relationship intentions (Kumar et al., 2003:690). This view is supported by Conze, Bieger, Laesser and Riklin (2010:58) as well as Mentz (2014:233) who found a positive relationship between relationship intention and loyalty. Research among Generation Y also established a relationship between loyalty and behavioural intentions (Foscht et al., 2009:241) and furthermore established a positive relationship between Generation Y's loyalty and their relationship intentions (Bresler, 2013:140,162). The following alternative hypothesis is accordingly formulated:

H3: There is a direct positive relationship between brand loyalty and relationship intention among Generation $Y$ consumers regarding smart phone brands.

Figure 1 presents the theoretical model of the hypothesised interrelationships between the constructs of this study.

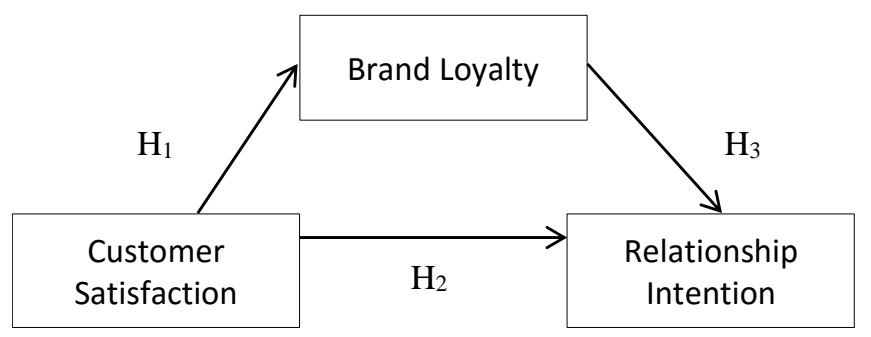

Figure 1: The theoretical model

\section{Research methodology}

Research context, population, sample and data
collection

The Generational theory maintains that there are cohorts of people grouped according to the particular generation to which they belong (Beckendorff, Moscardo \& Prendergast, 2010:1). Marketers are interested in grouping customers in the same way, as it is thought that people of a specific generation share characteristics, owing to their shared experiences (Kaser, 2012:79). Four main generational categories can be distinguished, namely Generation Y (also called Millennial); Generation X; Baby Boomers; and Matures (Lamb, Hair \& McDaniel, 2012:63; Osoba, 2013). For the purpose of this study, Generation Y was considered to be young adults, including the age group of 18 to 26 years, conforming to the categorisation proposed by Clow and Baack (2007:115) and Schroer (2004). Generation Y was selected since this cohort is leading the way when it comes to the adoption of smart phones (Lesonsky, 2013) and they generally have a good technological command and engage in technology-related behaviour (Rhynes \& Students, 2011:24; Nazareth, 2007:82).

The population for this study was therefore comprised of Generation Y smart phone owners between the ages of 18 and 26, residing in the Gauteng province, South Africa. As a sampling frame was not available, the researchers used a twostage non-probability sampling technique whereby the study population was divided into quotas based on gender grouping before the quotas were filled by means of convenience sampling. A sample size of 400, comprising 200 males and 200 females, was considered adequate (Mooi \& Sarstedt, 2011:42). The respondents were selected by 39 trained fieldworkers.

\section{Questionnaire design}

A self-administered questionnaire, mainly consisting of closed-ended questions, was used to collect the data. The questionnaire commenced with two screening questions to ensure that the prospective respondents qualified to take part in the study. The questionnaire comprised three sections. The first section was devoted to the respondents' demographic information, and was followed by a section capturing their smart phone usage patterns, including their network service provider, the customer type (i.e. either pre-paid or contract customer) and their current smart phone brand. The final section determined the respondents' level of customer satisfaction, their brand loyalty and their relationship intention towards their smart phone brand. All the items were measured on unlabelled Likert-type scales, where 1 represented 'strongly disagree' and 5 represented 'strongly agree'. The respondents' satisfaction and brand loyalty were measured by using items adopted from Dagger and Sweeney's work (2007), whereas the relationship intention measure was adapted from the scale proposed by Kruger (2014:184). The questionnaire for this study was pretested among 30 respondents selected on the basis of convenience 
from the study population. No changes were made to the questionnaire after it had been pretested.

\section{Data analysis}

Descriptive statistics were calculated to determine a sample profile and the cell phone network and the respondents' smart phone usage habits. Exploratory Factor Analyses (EFAs), using principal axis factoring with direct oblimin rotation, were conducted to assess the validity of the constructs. The internal consistency reliability of the measurement scales was established by calculating and assessing Cronbach's alpha values (Hair, Black, Babin, Anderson \& Tatham, 2010:93). Once validity and reliability could be established, the overall mean scores were calculated for customer satisfaction, brand loyalty, relationship intention and the dimensions of relationship intention.

Structural equation modelling (SEM) was used to determine the fit of the measurement model, and the model fit was assessed through four fit indices: the relative chi-square value $\left(X^{2} / \mathrm{df}\right)$, the root mean square error approximation (RMSEA), the Tucker-Lewis index (TLI) and the comparative fit index (CFI) (Bowen \& Guo, 2012:145; Bryman \& Cramer, 2011:147; Kremelberg, 2011:395). The structural equation modelling was executed by using Amos Version 21.

The regression weights of the structural model are also reported to indicate whether the interrelationships between customer satisfaction, brand loyalty and the dimensions of relationship intention are significant at a 0.001 level (Cohen, 1988:413). Suhr (2006:4) indicates that a value of less than 0.10 represents a small direct effect, a value in the region of 0.3 represents a medium direct effect and a value in the region of 0.5 represents a large direct effect.

\section{Results}

Sample profile, cell phone network and smart phone usage habits

A total of 395 questionnaires were suitable for analysis, with an almost equal number of males (49.9\%) and females $(50.1 \%)$ participating in the study, owing to the application of a gender quota. The majority of the respondents' household languages were English (38.7\%), Afrikaans (18\%), Sotho
(Sepedi, SeSotho, Tswana) (16.7\%) or Nguni (Zulu, Xhosa, Swati, Ndebele) (14.7\%).

When it came to the respondents' cell phone network and smart phone usage habits, it was determined that most of the respondents were customers of Vodacom (44.6\%), MTN $(36.5 \%)$ or Cell C (13.9\%). Regarding smart phone ownership, most of the respondents indicated that they owned a Blackberry $(56.5 \%)$, a Nokia $(14.9 \%)$ or a Samsung $(11.6 \%)$ smart phone. The remainder of the respondents owned an Apple iPhone (8.6\%), an HTC (4.8\%), a Sony Ericsson $(2.3 \%)$, a Motorola $(0.5 \%)$ or another $(0.8 \%)$ smart phone brand.

\section{Validity and reliability}

The EFAs conducted to assess the validity of the measurement scales measuring the constructs of the study produced several findings. The 12 items measuring customer satisfaction were all retained and subsequently one factor, explaining $53.26 \%$ of the variance, was extracted; the eight items measuring brand loyalty were all retained and subsequently one factor was extracted, explaining $66.76 \%$ of the variance. Relationship intention consists of five factors and the items measuring involvement, fear of relationship loss, forgiveness, feedback and expectations respectively were all retained and single factors explaining variances ranging between $56.44 \%$ and $68.94 \%$ were extracted. The Kaiser-Meyer-Olkin (KMO) values exceeded 0.7 (ranging between 0.8 and 0.9 ). In all instances only one factor could be extracted, explaining in excess of $50 \%$ of the variance. Factor loadings of items on respective constructs exceeds 0.5 , thus confirming convergent validity.

Table 1 demonstrates that customer satisfaction, brand loyalty and the measuring sets measuring relationship intention all realised Cronbach's alpha values above the cutoff point of 0.7 (Tan, 2011:74); ranging between 0.7 and 0.9 . Based upon these results, the scales measuring customer satisfaction and brand loyalty, and the dimensions of relationship intention can therefore all be considered reliable. Subsequently overall mean scores and standard deviations were calculated for each measurement set of factor. These are reflected in Table 1.

Table 1: EFA results and descriptive statistics for the measurement sets

\begin{tabular}{l|l|l|l|l}
\hline Measurement set & $\begin{array}{l}\text { Factors } \\
\text { extracted }\end{array}$ & $\begin{array}{l}\text { Cumulative } \\
\text { percentage } \\
\text { variance explained }\end{array}$ & $\begin{array}{l}\text { Cronbach's alpha } \\
\text { values }\end{array}$ & $\begin{array}{l}\text { Overall } \\
\text { score }\end{array}$ \\
\hline Customer satisfaction (13 items) & 1 & $53.98 \%$ & 0.9 & 3.98 \\
\hline Brand loyalty (8 items) & 1 & $66.67 \%$ & 0.9 & 3.45 \\
\hline Overall Relationship intention & & & 0.8 & 3.42 \\
\hline Involvement (5 items) & 1 & $56.34 \%$ & 0.7 & 3.89 \\
\hline Fear of relationship loss (5 items) & 1 & $66.20 \%$ & 0.9 & 3.12 \\
\hline Forgiveness (6 items) & 1 & $68.94 \%$ & 0.9 & 1.304 \\
\hline Feedback (5 items) & 1 & $62.45 \%$ & 0.8 & 1.066 \\
\hline Expectations (6 items) & 1 & $61.28 \%$ & 0.9 & 3.79 \\
\hline
\end{tabular}




\section{Measurement model}

Initial investigation of the SEM results revealed that two items measuring customer satisfaction had low standardised estimates and were subsequently removed: I believe that my current smart phone provider can enhance its products provided and I believe that my current smart phone provider can enhance its services provided. The other items for the customer satisfaction construct were retained for further analysis, as were all the items measuring brand loyalty and those measuring the five dimensions of relationship intention. The extent of the measurement model fit was assessed through four indices: the relative chi-square value $\left(X^{2} / \mathrm{df}\right)$, the root mean square error approximation (RMSEA), the TuckerLewis index (TLI) and the comparative fit index (CFI) (Bowen \& Guo, 2012:145; Bryman \& Cramer, 2011:147; Kremelberg, 2011:395).

Table 2 presents the fit indices (after the two items had been removed) and the recommended cut-off points for the measurement model.

Table 2: Fit indices for the measurement model

\begin{tabular}{l|l|l}
\hline Fit indices & $\begin{array}{l}\text { Recommended } \\
\text { cut-off points }\end{array}$ & $\begin{array}{l}\text { Fit indices } \\
\text { value }\end{array}$ \\
\hline $\begin{array}{l}\text { Chi-square/degrees of } \\
\text { freedom (relative chi- } \\
\text { square value) }\end{array}$ & $\leq 5.00$ & $\begin{array}{l}X^{2} / \mathrm{df} \\
981.564 / 227 \\
=4.3 *\end{array}$ \\
\hline CFI & $\geq 0.90$ & $0.9 *$ \\
\hline TLI & $\geq 0.90$ & $0.9 *$ \\
\hline RMSEA & $\leq 0.05$ or $\leq 0.08$ & 0.09 \\
\hline rounded to one decimal &
\end{tabular}

Table 2 shows that the relative chi-square value is 4.3 . This value indicates acceptable fit, as it is less than 5.0 (Sarantakos, 2007:70). The CFI value of 0.9 suggests an acceptable model fit (Bartholomew, Knott \& Moustaki, 2011:221; Mueller, 1996). The TLI value of 0.9 also reflects an acceptable model fit (Schumacker \& Lomax, 2004:82). The RMSEA value of 0.09 is not $\leq 0.08$ and therefore slightly exceeds the recommended cut-off point for what is considered a good fit (Moutinho \& Hutcheson, 2011:307). Considering all the fit indices in combination, acceptable model fit is evident.

\section{Structural model}

Acceptable fit for the structural model was also confirmed $\left(X^{2} / \mathrm{df}=4.205, \mathrm{CFI}=0.9, \mathrm{TLI}=0.9\right.$ and RMSEA $\left.=0.09\right)$ and subsequently Table 3 presents the regression weights and significance levels estimating the relationships between the different constructs in the model.
Table 3: Regression weights of the structural model

\begin{tabular}{|c|c|c|}
\hline Relationships & $\begin{array}{l}\text { 及 weight } \\
\text { (estimate) }\end{array}$ & p-value* \\
\hline $\begin{array}{l}\text { Customer satisfaction } \rightarrow \text { Brand } \\
\text { loyalty }\end{array}$ & 0.812 & $<0.001 *$ \\
\hline $\begin{array}{l}\text { Brand loyalty } \rightarrow \text { Relationship } \\
\text { intention }\end{array}$ & 0.266 & $<0.001 *$ \\
\hline $\begin{array}{l}\text { Customer satisfaction } \rightarrow \\
\text { Relationship Intention }\end{array}$ & 0.204 & $<0.001^{*}$ \\
\hline $\begin{array}{l}\text { Expectation } \rightarrow \text { Relationship } \\
\text { intention }\end{array}$ & 1.000 & $<0.001 *$ \\
\hline Feedback $\rightarrow$ Relationship intention & 1.131 & $<0.001^{*}$ \\
\hline $\begin{array}{l}\text { Forgiveness } \rightarrow \text { Relationship } \\
\text { intention }\end{array}$ & 0.872 & $<0.001 *$ \\
\hline $\begin{array}{l}\text { Fear of relationship loss } \rightarrow \\
\text { Relationship intention }\end{array}$ & 1.794 & $<0.001 *$ \\
\hline $\begin{array}{l}\text { Involvement } \rightarrow \text { Relationship } \\
\text { intention }\end{array}$ & 2.007 & $<0.001 *$ \\
\hline
\end{tabular}

When examining the regression weights and corresponding significance levels of the structural model, Table 3 shows that the interrelationships between customer satisfaction, brand loyalty and relationship intention are significant (p-value $<0.001$ ), with estimates ranging between 0.204 and 0.812 . The relationships between the dimensions of relationship intention and the relationship intention construct itself are also significant at a 0.001 level, with estimates ranging between 0.873 and 2.007 .

In Table 4, the standardised regression weights of the structural model are depicted.

Table 4: Standardised regression weights of the structural model

\begin{tabular}{l|l|l}
\hline Relationships & $\begin{array}{l}\boldsymbol{\beta} \text { weight } \\
\text { (estimate) }\end{array}$ & $\begin{array}{l}\text { Size of direct } \\
\text { effect }\end{array}$ \\
\hline $\begin{array}{l}\text { Customer satisfaction } \rightarrow \text { Brand } \\
\text { loyalty }\end{array}$ & 0.673 & Large \\
\hline $\begin{array}{l}\text { Brand loyalty } \rightarrow \text { Relationship } \\
\text { intention }\end{array}$ & 0.536 & Medium \\
\hline $\begin{array}{l}\text { Customer satisfaction } \rightarrow \\
\text { Relationship Intention }\end{array}$ & 0.340 & Medium \\
\hline $\begin{array}{l}\text { Expectation } \rightarrow \text { Relationship } \\
\text { intention }\end{array}$ & 0.467 & Medium \\
\hline $\begin{array}{l}\text { Feedback } \rightarrow \text { Relationship } \\
\text { intention }\end{array}$ & 0.467 & Medium \\
\hline $\begin{array}{l}\text { Forgiveness } \rightarrow \text { Relationship } \\
\text { intention }\end{array}$ & 0.356 & Medium \\
\hline $\begin{array}{l}\text { Fear of relationship loss } \rightarrow \\
\text { Relationship intention }\end{array}$ & 0.681 & Large \\
\hline $\begin{array}{l}\text { Involvement } \rightarrow \text { Relationship } \\
\text { intention }\end{array}$ & 0.769 & Large \\
\hline
\end{tabular}

It is evident from Table 4 that all the standardised regression weights for the constructs are positive, ranging between 0.340 and 0.769, with medium to large direct effects (Suhr, 2006).

Figure 2 graphically illustrates the structural model, showing the relationships between the three main constructs of the 
study: customer satisfaction, brand loyalty and relationship intention.

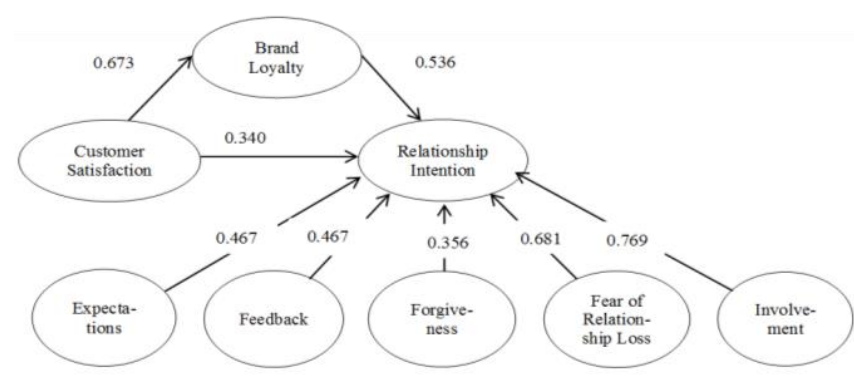

Figure 2: The structural model

The following conclusions regarding the hypotheses formulated for the study can therefore be made:

- Hypothesis $\mathrm{H}_{1}$, stating that there is a direct positive relationship between customer satisfaction and brand loyalty to smart phone brands among Generation $\mathrm{Y}$ consumers should be supported $(\beta=0.673 ; p<0.001$; large effect);

- Hypothesis $\mathrm{H}_{2}$, stating that there is a direct positive relationship between customer satisfaction and relationship intention towards smart phone brands among Generation Y consumers should be supported ( $\beta$ $=0.340 ; \mathrm{p}<0.001$; medium effect);

- Hypothesis $\mathrm{H}_{3}$, stating that there is a direct positive relationship between brand loyalty and relationship intention among Generation $\mathrm{Y}$ consumers regarding smart phone brands should be supported $(\beta=0.536$; $\mathrm{p}<$ 0.001; medium effect).

\section{Conclusions and recommendations}

The literature review established that customer relationships have become a major focus by marketers in an effort to increase customer loyalty and ultimately to retain customers (Adjei \& Clark, 2010:73; Mende et al., 2013:125; Wang \& $\mathrm{Ha}, 2011: 337)$, as the loss of potential lifetime customers could result in lower profits (Pride \& Ferrell, 2011:400). In order to retain Generation $\mathrm{Y}$ customers, it is critical for organisations to provide customer satisfaction, generate brand loyalty and build meaningful, long-term relationships with them. However, not all customers want to build longterm relationships, so it is essential to identify and focus on those customers with higher relationship intentions (Kumar et al., 2003:690).

Results from this study indicate that there is a direct positive relationship between customer satisfaction and brand loyalty to smart phone brands among Generation Y consumers. These results corroborate literature suggesting that brand loyalty cannot exist without customer satisfaction (Chandrasekar, 2010:152; Hofmeyr \& Rice, 2003; Levine, 2003:204,206). It is therefore recommended that smart phone marketers develop their understanding of Generation Y's needs and offer products and services to not only meet, but also exceed their needs. If they do this, marketers stand a greater chance of building brand loyalty in an effort to obtain higher profits and build brand equity (O'Guinn et al., 2011:31; Sharma et al., 2010:239).

Further, the results indicate that there is a direct positive relationship between customer satisfaction and relationship intention towards smart phone brands among Generation Y consumers. This finding supports Mentz's (2014:233) opinion that a relationship exists between customer satisfaction and relationship intention. It reinforces the importance of ensuring customer satisfaction. If smart phone marketers were to act on this, they would stand a greater chance of building long-term relationships with their customers. Further, the finding accords with the literature (Keiningham et al., 2007; Purohit, 2004:2) suggesting that, due to the relationship between customer satisfaction and relationship intention, it could be easier for marketers to build long-term relationships with customers. Building such relationships is possible by ensuring that customer expectations are not only met, but exceeded to ensure at least customer satisfaction, if not customer delight.

Finally, the results also indicate that there is a direct positive relationship between brand loyalty and relationship intention to smart phone brands among Generation Y consumers. This finding supports the finding from Mentz's (2014:233) study that a relationship exists between relationship intention and customer loyalty, which gives greater support to the initial suggestion by Kumar et al. (2003:690) that organisations would stand a better chance of building brand loyalty with customers who show relationship intentions. Given this, it becomes increasingly important for smart phone marketers to move customers from brand recognition and preference to brand insistence (Ferrell \& Hartline, 2011:204; Pride \& Ferrell, 2011:400), in an effort to form long-term relationships with customers, especially those showing relationship intentions, as the results support a direct positive relationship between brand loyalty and relationship intention.

It can furthermore be recommended that smart phone marketers should segment their customers on the basis of their relationship intentions, thereby ensuring that optimal resources are invested in building relationships with customers who display high relationship intentions. This implies that smart phone marketers should have a sound knowledge of the underlying constructs comprising customers' relationship intentions and are able to measure these constructs in order to develop effective strategies for maintaining and improving on each measurement construct.

As a final recommendation, it is suggested that smart phone marketers manage (measure and control) the relationships between customer satisfaction, brand loyalty and relationship intention, because to neglect one of the constructs would have a negative effect on the other, thereby impacting negatively on attempts directed at building long-term relationships with Generation Y customers. 


\section{Limitations of the study and directions for future research}

First, the non-probability sampling method used in this study has an inherent limitation with respect to the generalisability of results to a broader population. Future studies should therefore consider a probability sampling technique. A second limitation is that, despite the questionnaire's length of only four pages, some incomplete questionnaires were returned, as certain respondents lost interest while completing the questionnaire. Future studies should therefore attempt to use a briefer questionnaire to encourage Generation $\mathrm{Y}$ respondents' participation or a different way to collect the information (for example personal interviews or phone calls, etc.).

As indicated in the literature overview, customer expectations play a vital role in determining customer satisfaction (Helgesen, 2007:280; Nijssen \& Van Herk, 2009:96). It can thus be recommended that, if they want to increase Generation Y's customer satisfaction, smart phone marketers will have to conduct research to determine this generation's current and expected future expectations (expressed as needs). This implies possibly developing smart phones and apps tailored specifically for Generation Y.

It is recommended that the constructs of this study be further investigated in future research and that a qualitative in-depth approach be considered to determine the reasons why respondents experience customer satisfaction, brand loyalty and relationship intention to their smart phones.

\section{References}

Adjei, M.T. \& Clark, M.N. 2010. 'Relationship marketing in a B2C context: The moderating role of personality traits', Journal of Retailing and Consumer Services, 17:73-79.

Alamro, A. \& Rowley, J. 2011. 'Antecedents of brand preference for mobile telecommunications services', Journal of Product and Brand Management, 20(6):475-486.

Babin, B.J. \& Harris, E.G. 2011. Cb2. Student edition. Belmont, CA: Wadsworth Cengage Learning.

Bartholomew, D., Knott, M. \& Moustaki, I. 2011. Latent variable models and factor analysis: A unified approach. 3rd Edition. Hoboken, NJ: Wiley.

Beckendorff, P., Moscardo, G. \& Pendergast, D. 2010. Tourism and generation Y: Their expectations and experiences at the winery cellar door. In P. Beckendorff, G. Moscardo \& D. Pendergast (Eds.). Tourism and Generation Y. Wallingford: CABI.

Bowen, N.K. \& Guo, S. 2012. Structural equation modelling. New York: Oxford University Press.

Bresler, M. 2013. Black generation Y expectations of their banks' customer relationship management. Unpublished Masters dissertation. University of Johannesburg.
Bryman, A. \& Cramer, D. 2011. Quantitative data analysis with IBM SPSS 17, 18 \& 19: A guide for social scientists. New York: Routledge.

Chandrasekar, K.S. 2010. Marketing management: Text and cases. New Delhi: Tata McGraw-Hill.

Choy, J.Y., Lam, S.Y. \& Lee, T.C. 2012. 'Service quality, customer satisfaction and behavioral intentions: Review of literature and conceptual model development', International Journal of Academic Research, 4(3):11-15.

Clow, K. \& Baack, D. 2007. Integrated advertising, promotion, and marketing communications. 3rd Edition. Upper Saddle River, NJ: Pearson Prentice Hall.

Cohen, J. 1988. Statistical power analysis for the behavioral sciences. 2nd Edition. Hillsdale, NJ: Erlbaum.

Conze, O., Bieger, T., Laesser, C. \& Riklin, T. 2010. 'Relationship intention as a mediator between relational benefits and customer loyalty in the tour operator industry', Journal of Travel \& Tourism Marketing, 27(1):51-62.

Dagger, T.S. \& Sweeney, J.S. 2007. 'Service quality attribute weights: How do short-term and longer-term customers construct service quality perceptions?', Journal of Service Research, 10(1):22-42.

Danova, T. 2015. The global smartphone report: These are the companies and regions that will drive the next billion smartphone shipments. [online] http://www.businessinsider.com/globalsmartphone-market-forecast-vendor-platform-growth-2015-6 Date of access: 14 August 2015

Doyle, P. 2008. Value-based marketing: Marketing strategies for corporate growth and shareholder value. 2nd Edition. West Sussex: Wiley.

Dunne, P.M., Lusch, R.F. \& Carver, J.R. 2011. Retailing. 7th Edition. Belmont, CA: Cengage Learning.

Egner, T. 2008. Customer oriented and efficient account planning: A prerequisite for profitable growth. Munchen: Grin Verlag.

Ferrell, O.C. \& Hartline, M.D. 2011. Marketing strategy. 5th Edition. Belmont, CA: Cengage Learning.

Foscht, T., Schloffer, J., Maloles III, C. \& Chia, S.L. 2009. 'Assessing the outcomes of generation-Y customers' loyalty', International Journal of Bank Marketing, 27(3):218-241.

Gamble, P.R., Stone, M., Woodcock, N. \& Foss, B. 2006. Up close and personal: Customer relationship marketing @ work. 3rd Edition. London: Kogan Page.

Golder, P.N., Mitra, D. \& Moorman, C. 2012. 'What is quality? An integrative framework of processes and states', Journal of Marketing, 76(4):1-23.

Goldstein, S.D. 2009. Superior customer satisfaction and loyalty: Engaging customers to drive performance. Milwaukee: Quality Press.

Gorun, M. 2011. Millennials require reward for brand loyalty. [online] http://worlddealer.wordpress.com/2011/12/27/millennialsrequire-reward-for-brand-loyalty/ Date of access: 6 February 2012. 
Gurău, C. 2012. 'A life-stage analysis of consumer loyalty profile: Comparing generation $\mathrm{x}$ and millennial consumers', Journal of Consumer Marketing, 29(2):103-113.

Hair, J.H., Black., W.C., Babin, B.J., Anderson, R.E. \& Tatham, R.L. 2010. Multivariate data analysis. 7th Edition. Upper Saddle River, NJ: Prentice Hall.

Helgesen, Ø. 2007. 'Drivers of customer satisfaction in business-tobusiness relationships: A case of Norwegian fish exporting companies operating globally', British Food Journal, 109(10):819837.

Hoffman, K.D. \& Bateson, J.E.G. 2011. Services marketing: concepts, strategies and cases. 4th Edition. Belmont, CA: Cengage Learning.

Hofmeyr, J. \& Rice, B. 2003. Commitment-led marketing: The key to brand profits is in the customer's mind. Cape Town: Juta.

Hong, D. 2012. Bringing the contact center to the Smartphone. [online] http://www.Ovum.com Date of access: 22 April 2012.

Hougaard, S. \& Bjerre, M. 2003. Strategic relationship marketing. Berlin: Springer.

Humphrey, D.D. 2011. 21 st century business: Customer service. 2nd ed. Belmont, Calif.: Cengage Learning.

Hutcheson, G.D. \& Moutinho, L. 1998. 'Measuring preferred store satisfaction using consumer choice criteria as a mediating factor', Journal of Marketing Management, 14(7):705-720.

IDC (International Data Corporation). 2015. Global smartphone growth expected to slow to $11.3 \%$ in 2015 as market penetration increases in top markets, according to IDC. [online] http://www.idc.com/getdoc.jsp?containerId=prUS25641615 Date of access: 14 August 2015

Iglesias, O., Sauquet, A. \& Montaña, J. 2011. 'The role of corporate culture in relationship marketing', European Journal of Marketing, 45(4):631-650.

Jena, S., Guin, K.K. \& Dash, S.B. 2011. 'Effect of relationship building and constraint-based factors on business buyers' relationship continuity intention', Journal of Indian Business Research, 3(1):22-42.

Jensen, J.M. \& Hansen, T. 2006. 'An empirical examination of brand loyalty', Journal of Product and Brand Management, 15(7):442-449.

Kaplan, R.S. \& Norton, D.P. 2006. Alignment: Using the balanced scorecard to create corporate synergies. Boston, MA: Harvard Business School Publishing.

Kaser, K. 2012. Advertising and sales promotion. Belmont, CA: Cengage Learning.

Keiningham, T.L., Cooil, B., Aksoy, L., Andreassen, T.W. \& Weiner, J. 2007. 'The value of different customer satisfaction and loyalty metrics in predicting customer retention, recommendation and share-of-wallet', Managing Service Quality, 17(4):361-384.

Kremelberg, D. 2011. Practical statistics: A quick and easy guide to IBM SPSS statistics, STATA, and other statistical software. Belmont, CA: Sage.
Kruger, L. 2014. Determining the influence of relationship intention on satisfaction, loyalty and retention following service recovery. Unpublished $\mathrm{PhD}$ thesis, North-West University: Potchefstroom.

Kumar, A. \& Lim, H. 2008. 'Age differences in mobile service perceptions: Comparison of generation Y and baby boomers', Journal of Services Marketing, 22(7):568-577.

Kumar, V., Bohling, T.R. \& Ladda, R.N. 2003. 'Antecedents and consequences of relationship intention: Implications for transaction and relationship marketing', Industrial Marketing Management, 32(8):667-676.

Lamb, C.W., Hair, J.F. \& McDaniel, C. 2012. Essentials of marketing. 7th Edition. Belmont, CA: Cengage Learning.

Lazarevic, V. 2012. 'Encouraging brand loyalty in fickle generation Y consumers', Young Consumers, 13(1):45-61.

Lee, S., Johnson, K.K.P. \& Gahring, S.A. 2008. 'Small town consumers' disconfirmation of expectations and satisfaction with local independent retailers', International Journal of Retail \& Distribution Management, 36(2):143-157.

Lesonsky, R. 2013. Who's got smartphones and apps? Gen Y. [online] http://www. Networksolutions.Com Date of access: 5 September 2013.

Levine, M. 2003. A branded world: Adventures in public relations and the creation of superbrands. Hoboken, NJ: Wiley.

Liu, Y. 2007. 'The long-term impact of loyalty programs on consumer purchase behavior and loyalty', Journal of Marketing, 71(4):19-35.

Liu, Y. 2008. An analysis service quality, customer satisfaction and customer loyalty of commercial swim clubs in Taiwan. Ann Arbor, MI: Proquest.

Longenecker, J.G., Petty, J.W., Palich, L.E. \& Moore, C.W. 2009. Small business management: Launching and growing entrepreneurial ventures. 15th Edition. Belmont, CA: Cengage Learning.

Lovelock, C.H. \& Wirtz, J. 2011. Services marketing: People, technology, strategy. 7th Edition. Boston, Mass.: Pearson.

Mahadoo, S. 2010. The evolution of smart phones. [online] http://www.Cellhub.Com Date of access: 1 March 2012.

Markets and Markets. 2011. Mobile phone and smartphone market global forecast (2010-2015). [online] http://www.Marketsandmarkets.com Date of access: 1 March 2012.

Meek, F. 2011. Seomobile marketing: the preferred channel for Generation Y. [online] http://www.Dailyseotip.Com Date of access: 7 February 2012.

Mende, M., Bolton, R.N. \& Bitner, M.J. 2013. 'Decoding customerfirm relationships: How attachment styles help explain customers' preference for closeness, repurchase intentions, and changes in relationship breadth', Journal of Marketing Research, 125-142.

Mentz, M.H. 2014. Developing a framework for relationship intention, satisfaction, loyalty and retention of SMEs in the businessto-business financing environment. Unpublished $\mathrm{PhD}$ thesis, NorthWest University: Potchefstroom. 
Mooi, E. \& Sarstedt, M. 2011. A concise guide to market research: The process, data, and methods using IBM SPSS statistics. New York: Springer.

Moutinho, L. \& Hutcheson, G. 2011. The Sage dictionary of quantitative management research. London: Sage.

Mueller, R.O. 1996. Basic principles of structural equation modeling: An introduction to LISREL and EQS. New York: Springer.

Nazareth, L. 2007. The leisure economy: How changing demographics, economics and generational attitudes will reshape our lives and our industries. Mississauga, Ont., Canada: John Wiley $\&$ Sons.

Nijssen, E.J. \& Van Herk, H. 2009. 'Conjoining international marketing and relationship marketing: Exploring customers' crossborder service relationships', Journal of International Marketing, 17(1):91-115.

O'Guinn, T.C., Allen, C.T. \& Semenik, R.J. 2011. Advertising and integrated brand promotion. 6th ed. Belmont, CA.: Cengage Learning.

Oliver, R.L. 1997. Satisfaction: A behavioral perspective on the consumer. New York: McGraw-Hill.

Osoba, L. 2013. Are you using generational marketing to speak in your customer's language? [online] http://www.Primeconcepts.Com Date of access: 2 September 2013.

Palmer, A. 2011. Principles of services marketing. 6th Edition. London: McGraw-Hill Companies.

Pride, W.M. \& Ferrell, O.C. 2011. Marketing express. 2nd ed. Belmont, CA: Cengage Learning.

Pride, W.M., Ferrell, O.C., Lukas, B. A., Schembri, S. \& Niininen, O. 2012. Marketing principles. Asia Pacific ed. Australia: Cengage Learning.

Purohit, H.C. 2004. Customer satisfaction and complaint behaviour. New Delhi, India: Krishan Mittal.

Raciti, M.M., Ward, T. \& Dagger, T.S. 2013. 'The effect of relationship desire on consumer-to-business relationships', European Journal of Marketing, 47(4):615-634.

Rao, K.R.M. 2011. Services marketing. 2nd ed. India: Dorling Kindersley.

Rhynes, M. \& Students. 2011. Write to live: Telling our stories. Lincoln, NE: iUniverse.

Sarantakos, S. 2007. A toolkit for quantitative data analysis: Using SPSS. New York: Palgrave MacMillan.

Schroer, W.J. 2004. Generations X, Y, Z and the others. [online] http://www.socialmarketing.org Date of access: 23 March 2012.

Schumacker, R.E. \& Lomax, R.G. 2004. A beginner's guide to structural equation modelling. 2nd Edition. Hillside, NJ: Erlbaum.

Seiders, K., Voss, G.B., Grewal, D. \& Godfrey, A.L. 2005. 'Do satisfied customers buy more? Examining moderating influences in a retailing extent', Journal of Marketing, 69(4):26-43.
Sharma, J.K., Singh, D., Deepak, K.K. \& Agrawal, D.P. 2010. Neuromarketing: A peep into customers' minds. New Delhi: Phi Learning.

Shimp, T.A. 2010. Advertising, promotion \& other aspects of integrated marketing communications. 8th Edition. Mason, $\mathrm{OH}$ : Cengage Learning.

Suhr, D.D. 2006. The basics of structural equation modelling. [online] http://www.lexjansen.com/wuss/2006/tutorials/TUT-Suhr Date of access: 8 July 2014

Sunarto, H. 2007. Understanding the role of bank relationships, relationship marketing, and organisational learning in the performance of people's credit bank. Tinbergen Institute Research Series, $44 . \quad$ [online] http://www.tinbergen.nl/wpcontent/uploads/2013/03/annualreport2007.pdf Date of access: 8 July 2014.

Sweeney, J.C., Soutar, G.N. \& McColl-Kennedy, Jr. 2011. 'The marketing practises-performance relationship in professional services organisations', Journal of Services Marketing, 22(3):292316.

Tan, F.B. 2011. International enterprises and global information technologies: Advancing management practices. Hershey, PA: Information Science Reference.

Thomas, A.R., Lewison, D.M., Hauser, W.J. \& Foley, L.M. 2007. Direct marketing in action: Cutting-edge strategies for finding and keeping the best customers. Westport, CT: Praeger.

Tshabalala, S. 2015. Growing cheaply: Africa's smartphone market is on the rise as affordable handsets spur growth. Quartz Africa. [online] http://qz.com/451844/africas-smartphone-market-is-onthe-rise-as-affordable-handsets-spur-growth/ Date of access: 14 August 2015

Tuominen, P. 2007. 'Emerging metaphors in brand management: Towards a relational approach', Journal of Communication Management, 11(2):182-191.

Tuu, H.H., Olsen, S.O. \& Linh, P.T.T. 2011. 'The moderator effects of perceived risk, objective knowledge and certainty in the satisfaction-loyalty relationship', Journal of Consumer Marketing, 28(5):363-375.

Veloutsou, C. \& McAlonan, A. 2012. 'Loyalty and or disloyalty to a search engine: The case of young millennials', Journal of Consumer Marketing, 29(2):125-135.

Wang, C.H. \& Ha, S. 2011. 'Store attributes influencing relationship marketing: A study of department stores', Journal of Fashion Marketing and Management, 15(3):326-344.

Wankel, C. 2009. Encyclopedia of business in today's world. Belmont, CA: Sage.

Wei, Y., Li, Z., Burton, J. \& Haynes, J. 2012. 'Are Chinese consumers created equally relational?', Management Research Review, 36(1):50-65.

Wilson, A., Zeithaml, V.A., Bitner, M.J. \& Gremler, D.D. 2012. Services marketing: Integrating customer focus across the firm. London: McGraw-Hill. 